\title{
Review of World Aquaculture and Oceanography
}

\author{
Sunil kumar P* \\ Sree Kerala Varma College, Kerala, India
}

Submission: February 17, 2017; Published: February 28, 2017

*Corresponding author: Sunil kumar P, Assistant professor, Sree Kerala Varma College, Thrissur, Kerala, India 680001, Tel: 9446323341; Email: sukkuedavetty2012@gmail.com

\section{Editorial}

The main objective of this issue is to publish most complete and reliable source of information on research and current developments in the areas of aquaculture and oceanography. This issue covers areas in marine, brackish water and environmental aspects of fisheries. It provides an international forum for publication of papers in areas of fisheries science and aquaculture. Aquaculture contributed 43 per cent of aquatic animal food for human consumption in 2007 and is expected to grow further to meet the future demand. It is very diverse and, contrary to many perceptions, dominated by shellfish and herbivorous and omnivorous pond fishes. The rapid growth in the production of carnivorous species such as salmon, shrimp and catfish has been driven by globalizing trade and favourable economics of larger scale intensive farming.

Aquaculture includes species at any tropic level that are grown for domestic consumption or export. Aquaculture has some positive impacts on biodiversity. Cultured seafood can reduce pressure on overexploited wild stocks, stocked organisms may enhance depleted stocks, aquaculture often boosts natural production and species diversity, and employment in aquaculture may replace more destructive resource uses. On the negative side, species that escape from aquaculture can become invasive in areas where they are nonnative, effluents from aquaculture can cause eutrophication, ecologically sensitive land may be converted for aquaculture use, aquaculture species may consume increasingly scarce fish meal, and aquaculture species may transmit diseases to wild fish. Most likely, aquaculture will continue to grow at significant rates through 2025, and will remain the most rapidly increasing food production system. In the area of aquaculture increased output is likely to require expansion in new environments, further intensification and efficiency gains for more sustainable and cost-effective production. The trend towards enhanced intensive systems with key monocultures remains strong and, at least for the foreseeable future, will be a significant contributor to future supplies. Dependence on external feeds, water and energy are key issues. Some new species will enter production and policies that support the reduction of resource footprints and improve integration could lead to new developments as well as reversing decline in some more traditional systems.

Aquaculture in the Asia•Pacific region has been growing steadily over the last few decades and to satisfy the demand of the local and export markets, many countries are expanding their aquaculture activities in the sea, including offshore areas where competition is less. Mariculture in finfish region is exceptionally biodiverse and relies on many species and hence the nature of mariculture is rapidly changing in this area. Regarding ocean climate sea level rise from heat expansion and melting land ice threaten coastal ecosystems and human habitats. Ocean climate changes through temperature, acidification and deoxygenation have direct impact on ocean ecosystems. Ocean contributes to global warming and accounts for about $93 \%$ of excess heat accumulated during recent years. The concentration of dissolved oxygen declines over the recent years and influence the distribution as well as abundance of all marine species. Global Ocean PH is decreasing causing an increase of acidity by about $30 \%$. More over pollution caused by atmosphere inputs of $\mathrm{CO} 2$ and $\mathrm{N} 2$ as well as solid debris is a rapidly emerging threat for the coastal flora and fauna.

The subject matter in this volume focused on aquaculture and fisheries with emphasis on conservation. The aim of this issue is to provide an update synopsis for research workers in the field of aquaculture and fisheries oceanography. The potential of aquaculture to meet the challenges of food security and to generate employment and foreign exchange is clearly demonstrated by the rapid expansion of this sector. The sustainable development and management of aquaculture and fisheries can only occur if these activities are well planned. 
Your next submission with Juniper Publishers will reach you the below assets

- Quality Editorial service

- Swift Peer Review

- Reprints availability

- E-prints Service

- Manuscript Podcast for convenient understanding

- Global attainment for your research

- Manuscript accessibility in different formats

( Pdf, E-pub, Full Text, Audio)

- Unceasing customer service

Track the below URL for one-step submission https://juniperpublishers.com/online-submission.php 